\title{
熱水の地山岩盤内貯蔵における 一二の問題点と対策
}

\author{
稲田善紀 ${ }^{1}$ - 木下尚樹 ${ }^{2}$ 松嶋信行 ${ }^{3}$ \\ 'フェロー会員 工博 愛媛大学教授 工学部環境建設工学科（テ790-8577 松山市文京町3） \\ ${ }^{2}$ 正会員 工修 愛媛大学助手 工学部環境建設工学科 \\ ${ }^{3}$ 学生会員 愛媛大学大学院 理工学研究科土木海洋工学専攻
}

\begin{abstract}
ゴミ焼却等で発生する廃熱を利用して水を熱水に変え, 多目的に利用する場合, 季節や一日の時間帯 による熱水の使用量の変動に関係なく，安定供給するための一時的な貯蔵施設が必要となる.土地の立 体的有効利用や環境保全等の観点から，地山岩盤内に空洞を設けて貯蔵することを想定した場合，空洞 周辺岩盤に発生する熱応力や, 空洞からの熱水の漏出が問題となる. 本研究では, 熱応力軽減対策とし て空洞表面に種々の断熱材を施すことを想定し，空洞周辺の温度分布および応力分布を求め，熱応力軽 減に有効な手段となることを示したままた，熱水の漏出防止対策として，種々の高分子系材料を空洞表 面にライニングした場合について検討し，漏出防止対策に有効な手段となることを示した.
\end{abstract}

Key Words : heated water storage, opening, reduction of thermal stress, preventing leakage, adiabatical material, resin

\section{1. 緒言}

筆者らはこれまで「熱水貯蔵システム」を提案し， 種々の検討を行ってきている(1) 省エネルギー対策の一環として，毎日のゴミ焼却等 で発生する廃熱を利用して水を熱水に変え，一般家 庭への給湯, 地域暖房, 温水プール, ビニールハウ ス等多目的に利用しようというもので，質の高い生 活を享受できるという点で, 地域の過疎化対策やゴ ミ焼却場の立地等にも有効であると考えられる.

多目的に熱水を使用する場合, 使用量が一日の時 間帯や季節によって変動することから, 安定供給の ための一時的な貯蔵を行う施設が必要となる。熱水 の貯蔵方法としては，地山岩盤内に空洞を設け一時 貯蔵することを筆者らは提案している ${ }^{1) \sim 4)}$. この方 法は，土地の立体的有効利用や環境の保全等で利点 があると考えられる。

これまでの研究から, 熱水貯蔵時には空洞周辺岩 盤に熱膨張による圧縮応力が空洞の接線方向に発生 することがわかっている ${ }^{1) 4)}$. また，貯蔵量の変動 により, 空洞周辺岩盤が熱の影響を繰り返し受ける
場合の熱的挙動についても一部報告している5),6). のように，周辺岩盤が熱履歴を受けることや，岩盤 には潜在的に亀裂が存在することなどを考慮すると， 空洞をより安定した状態で貯蔵するには熱応力を極 力軽減させる必要がある。また, 空洞からの熱水の 漏出も問題となってくる.

本研究では熱応力の軽減対策の一つの方法として, 空洞表面に断熱材を施すことを想定した。まず，高 温下における種々の断熱材の熱物性值を実験により 求め, 地山岩盤と想定している花崗岩と比較し, 高 温下における断熱材の熱的性質を把握した．次に要 素分割法”を複合材料にも適用できるように発展さ せ, これを用いて空洞周辺岩盤の温度分布の経時変 化を解析した. さらに温度分布を用いて忘力解析を 行い, 断熱材による熱応力軽減の効果について考察 した.

熱水の漏出防止対策としては, 空洞表面に高分子 系材料をライニングすることを想定した.ここでも まず，高温下における種々の高分子系材料の強度 • 変形特性および熱物性值を実験により求め, 求めた 值を用いて温度分布および応力分布を解析により求 


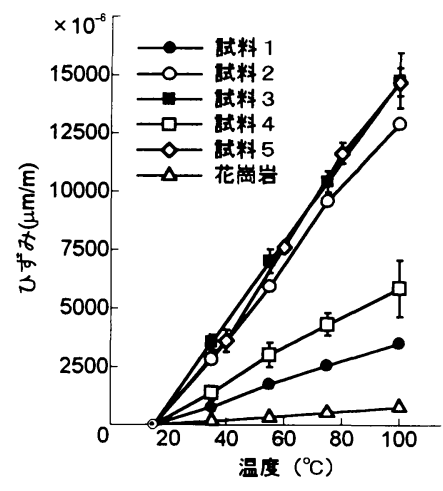

図-1 高温下における試料のひずみ

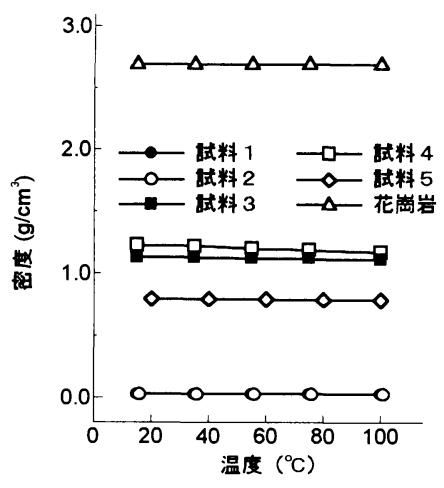

図-2 高温下における試料の密度

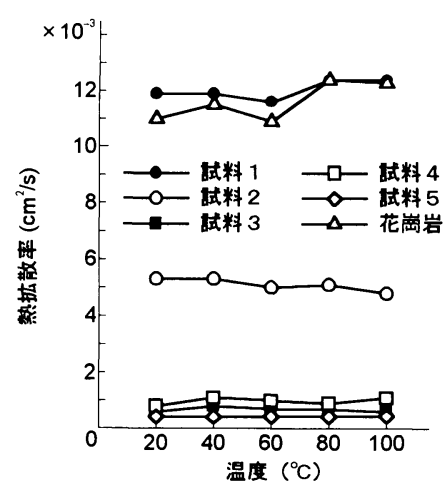

図-3 高温下における試料の熱拡散率
め, 漏出防止対策としての高分子系材料の適用性を 検討した. また, 熱応力軽減と漏出防止を同時に行 う方法についても考察した.

\section{2. 高温下における断熱材および高分子系材 料の熱物性值}

\section{（1）実験に用いた試料}

本実験で用いた断熱材はA社製の押出発泡ポリス チレン（以下試料1と呼ぶ）およびB社製の硬質ウレ タンフォーム（以下試料 2 と呼ぶ）である. 両者と も一般的に建築材料として用いられている断熱材で ある. 吸水率は前者が $0.01 \mathrm{~g} / \mathrm{cm}^{3}$ 以下, 後者が $0.025 \mathrm{~g} / \mathrm{cm}^{3}$ 以下であるが，実験に供する際には各実 験用に成形後, 室内で7日間自然乾燥し，これをデ シケータ内でさらに7日間乾燥した.

高分子系材料はC社製のエポキシ樹脂（以下試料3 と呼ぶ），D社製のビニルエステル樹脂（以下試料4 と呼ぶ）およびC社製のウレタン樹脂（以下試料5 呼ぶ）を用いた。 これらの高分子系材料は, 土木, 建築の分野では海水からの防蝕防水や接着剂, 耐酸 性が要求される場所のライニングとして用いられて いるものである. 試料3は重量比で $20 \%$, 試料4は2\% の硬化剂を加え, 試料5は体積比で $1: 1$ の硬化剂を加 えて型枠に打設し, 硬化させた. 硬化後, 脱型して 室内にて7日間以上養生し, 各実験用に成形した.

\section{(2)ひずみおよび密度}

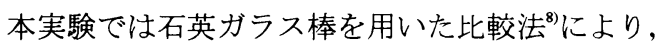
室温（ここでは $15^{\circ} \mathrm{C}$ ) から $100^{\circ} \mathrm{C}$ まで温度上昇に 伴うひずみを測定した，供試体は $\phi 3 \times 10 \mathrm{~cm}$ に成形 し, 端面の平行度および平坦度は $5 / 100 \mathrm{~mm}$ 以内とし
た。熱源にはヒーターを用い, 昇温速度は $1^{\circ} \mathrm{C} / \mathrm{min}$ とした．実験を行う際に供試体と同型の試料の中心 温度を測定した結果, 雾囲気温度が所定の温度に達 した後，遅いものでも約20分間で供試体全体が所定 の温度になることがわかった．また，ひずみの変化 も約20分間で収束したが，念のためひずみを測定し ながら60分間の保温を行った. 実験回数は最低3回 行った結果を平均した．結果を図-1に示す，図中に 示す值の幅は標準偏差を表している.いずれの試料 も温度の上昇に伴い, ほぼ直線的に膨張している. この場合, 花崗岩のひずみは $100^{\circ} \mathrm{C}$ で約 $800 \mu \mathrm{m} / \mathrm{m}$ で あった。試料1は花崗岩の約 5 倍, 試料 2 は約 17 倍, 試料3および試料 5 は約 19 倍, 試料4は約 8 倍で, 断熱 材, 高分子系材料は花崗岩に比べて熱膨張量が大き

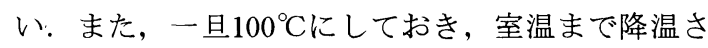
せた場合の残留ひずみは断熱材, 高分子系材料とも ほとんど測定されず，実用上は無視できるものと考 えられる.

ひずみから密度の変化を算出した結果が図-2であ る. 温度の上昇とともに密度は低下しており, 最も ひずみの大きかった試料 3 では $20^{\circ} \mathrm{C} か ら 100^{\circ} \mathrm{C}$ で約 5\%減少していた.

\section{（3）熱拡散率}

要素分割法に実測値を適用させる方法" 率を求めた。供試体は $15 \times 25 \times 10 \mathrm{~cm}$ に成形し，供試 体に1次元の熱伝導が得られるように5つの面を別の 断熱材（厚さ $20 \mathrm{~cm}$ ）で覆い，外気の影響を受けない ようにして，残りの1面 $(15 \times 10 \mathrm{~cm})$ に約 $100^{\circ} \mathrm{C}$ 熱 水を直接接触させた. この面から $5 \mathrm{~mm}$ 間隔で直径2 $\mathrm{mm}$, 深さ $50 \mathrm{~mm}$ の孔を 5 孔設け, 直径 $1 \mathrm{~mm}$ の熱電対 を挿入し，孔壁の熱源側に接触させ，間隙は試料の 粉を詰めた。これより得られる各距離における温度 


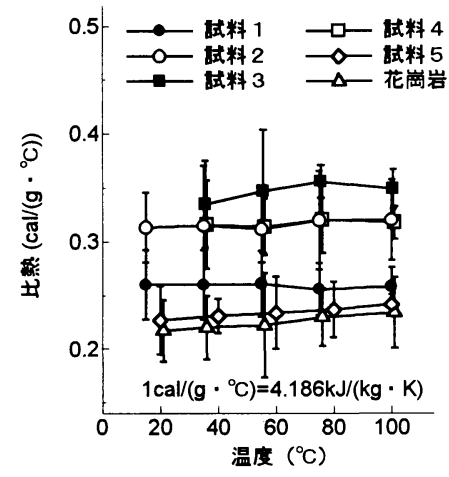

図-4 高温下における試料の比熱

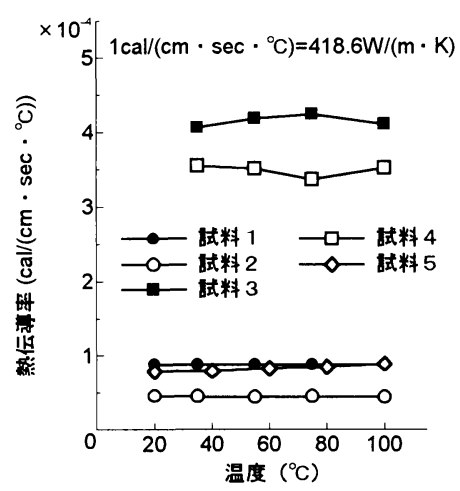

(a) 断熱材および高分子系材料

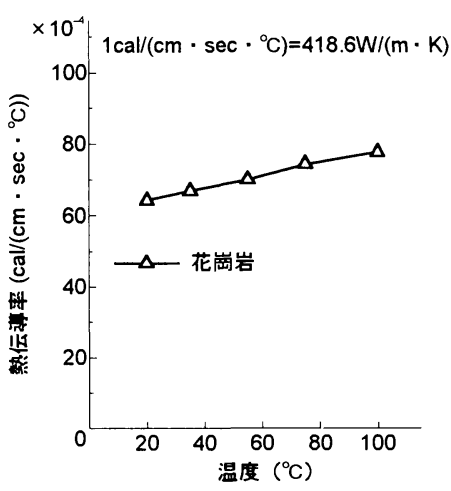

(b) 花崗岩

図-5 高温下における試料の熱伝導率

の経時変化を要素分割法に適用して，熱拡散率を求 めた．結果が図-3である，花岡岩の熱拡散率は 12.3 $\times 10^{-3} \mathrm{~cm} / \mathrm{s}$ 程度であった。断熱材の試料1は花岡岩と 同程度，試料 2 は $1 / 2$ 程度であった。これに対し，高 分子系材料の試料 3 および試料 4 は $1.0 \times 10^{-3} \mathrm{~cm} / \mathrm{s}$ 程度 で花岡岩の $1 / 10$ 以下, 試料 5 は $0.45 \times 10^{-3} \mathrm{~cm} / \mathrm{s}$ 程度で 花崗岩の1/20以下である.いずれの場合においても 温度による変化は大きくなく, 実用上は一定值とみ なせるものと考えられる。

\section{（4）比熱およひ熱伝導率}

比熱の測定に用いた供試体は熱の授受が効率よく 行える必要がある。ここでは40×40×5 mmに成形 したものを用いた。供試体の質量を予め測定して, 断熱ボックス内で $1{ }^{\circ} \mathrm{C} / \mathrm{min}$ で加熱し, 所定の温度で 60 分間保温した.この状態の供試体を蒸留水を入れた 断熱容器に投入し，摫找して温度変化を測定した. この温度変化から比熱を求めた結果が図-4である. 花崗岩の比熱が最も小さく, 試料 3 が最も大きいが $0.2 \sim 0.35 \mathrm{cal} /\left(\mathrm{g} \cdot{ }^{\circ} \mathrm{C}\right)$ 程度の值である. また，温度上 昇に伴う比熱の変化はいずれの試料でも小さい.

前述の密度, 熱拡散率および比熱から熱伝導率を 算出した結果が図-5(a)，(b)である，花岡岩は温度 の上昇とともに増加の傾向にあるが，他の試料は温 度に関係なくほぼ一定の值となった。断熱材の試料 1および試料2は花岡岩の熱伝導率の1/80～1/160程度, 高分子系材料の試料 3 および試料 4 は $1 / 20$ 程度，試料 5は1/80程度であった。これより断熱材は岩石と比 べ熱をきわめて遅く伝えることが予想される.

\section{3. 高温下における高分子系材料の強度・変 形特性}

\section{(1) 圧縮強度および引張強度}

一軸圧縮試験に用いた供試体は $\phi 30 \times 60 \mathrm{~mm}$ であ る.また，引張強度については花崗岩は圧裂試験と したため $\phi 30 \times 30 \mathrm{~mm}$ とした。端面の平行度および 平坦度は5/100mm以内になるように成形した。高分 子系材料は一軸引張試験としたため, 試料3および 試料4はダンベル型に，試料5は厚さ $3 \mathrm{~mm}$ のダンベル 状に成形した。強度試験の概念図を図-6に示寸。圧 縮試験時には供試体にひずみゲージを貼り付け，供 試体の縦ひずみおよび横ひずみを測定した。ひずみ ゲージおよびリード線の温度変化による影響はダミ ーゲージを用いてキャンセルした。供試体は加熱ボ ックス内で $1{ }^{\circ} \mathrm{C} / \mathrm{min}$ で加熱し，所定の温度に達した 後，60分間保温し，各実験を行った。なお，供試体

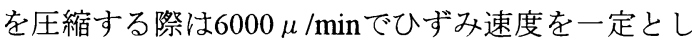
た. 各実験とも5回の試験を行い結果を平均した. 圧縮試験および引張試験の実験結果を図一7および図 -8に示す。高温下では高分子系材料は圧縮した場合 破壊には至らず，応力ーひずみ曲線が弾性的に立ち 上がり途中で傾きが変化し，その後は大きく塑性変 形していた。 そこで便宜的に，応力ーひずみ曲線が 変化する前後における2つの接線の交点を降伏点と 見なし, 降伏点での応力から求めた強度を圧縮強度 としている ${ }^{10)}$. 高分子系材料の圧縮強度, 引張強度 は温度の上昇に伴い著しく低下している。これは温 度が上昇すると熱膨張により分子間隔が広がる ${ }^{10)} こ$ とに起因しているものと考えられる. 


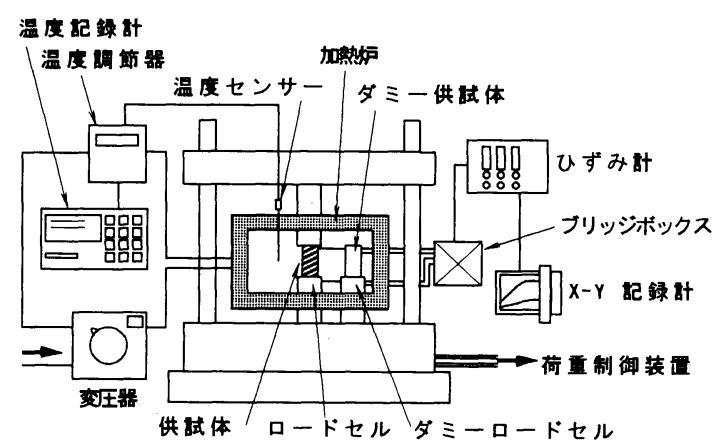

図-6 強度試験装置の概念図

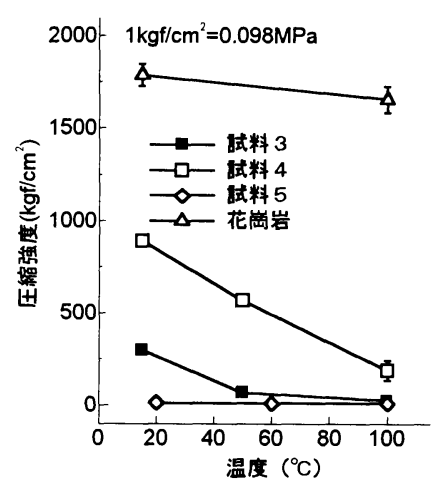

図-7 高温下における試料の圧縮強度

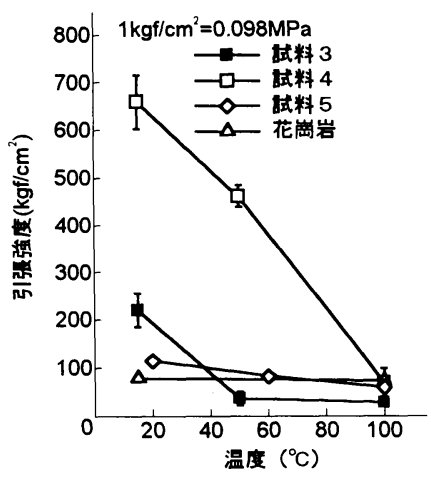

図-8 高温下における試料の引張強度

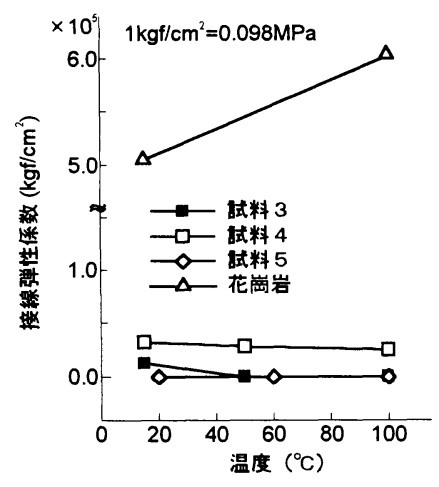

図-9 高温下における試料の 接線弾性係数

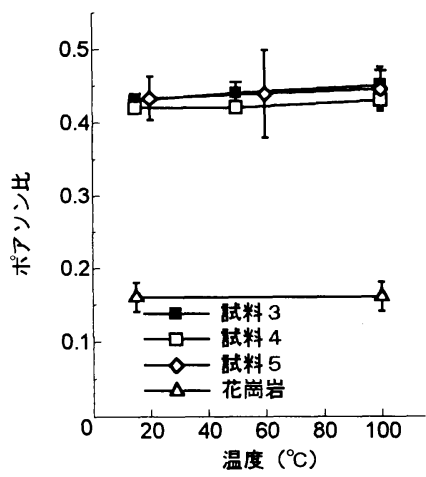

図-10 高温下における試料の ポアソン比
(2) 接線弾性係数およびポアソン比

圧縮試験時に得られた応力ーひずみ曲線から，破 壊応力 (高温下の高分子系材料では降伏応力) の $30 \%$ 付近での接線弾性係数およびポアソン比を求めた結 果が図-9および図-10である，高分子系材料の接線 弾性係数は花崗岩と比較し, 非常に小さいことがわ かる．また，温度の上昇とともに減少の傾向にあり， 高温下では変形しやすい性質を持っていることがわ かった。しかし，花崗岩では高温下では接線弾性係 数は上昇している。これは花崗岩は温度上昇に伴う 熱膨張によって岩石内部にも張り出し，空隙が見か け上密になり, 接線弾性係数が大きくなったものと 考えられる ${ }^{11)}$. 高分子系材料のポアソン比は花崗岩 に比べ大きく，温度の上昇に伴い，わずかではある が上昇の傾向にある．花崗岩ではポアソン比はわず かながら上昇しているが，実用上は変化はほとんど
ないとみなせる。

\section{4. 空洞周辺の温度分布の解析}

\section{(1) 要素分割法の原理}

本研究では熱水 $\left(100^{\circ} \mathrm{C}\right.$ 一定)を貯蔵した場合の空洞 周辺岩盤に生じる非定常の温度分布の経時変化を要 素分割法わにて求めた。断熱材を岩盤に施した場合 には，要素で熱物性值の異なる複合材料問題となる.

要素分割法にて複合材料問題を解く場合，図-11 示すように要素を矩形に分割した場合は，時閒 $\Delta \tau に$ 要素 $m-1$ から要素 $m$ に移動する熱量 $Q_{m-1, m}$ は式(1)で与 えられる。

$$
Q_{m-1, m}=-\lambda_{m-1} \frac{U_{m-1, n}^{(B)}-U_{m-1, n}}{\Delta X / 2} l_{m-1} \frac{1}{2} \Delta \tau
$$




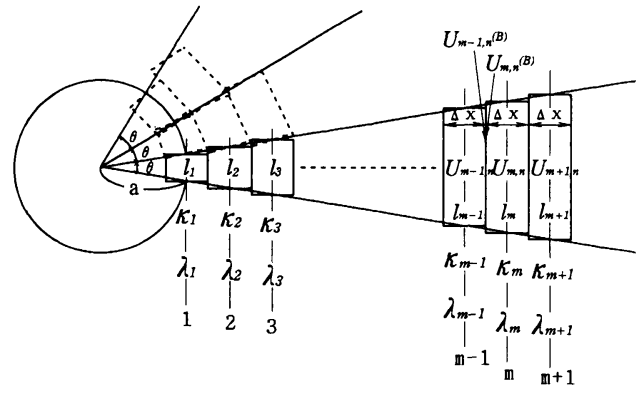

図-11 要素分割法の原理説明図 (2次元, 矩形要素分割)

$$
-\lambda_{m} \frac{U_{m, n}-U_{m, n}^{(B)}}{\Delta X / 2} l_{m} \frac{1}{2} \Delta \tau
$$

ただし, $\Delta X:$ 要素間隔

\section{$\lambda_{m}: m$ 番目の要素の熱伝導率}

$U_{m, n}:$ 時間 $n$ における $m$ 番目の要素の温度

$U_{m, n}^{(B)}:$ 時間 $n$ における $m-1$ 番目の要素と $m$ 番目の要素との境界の温度

$l_{m}: m$ 番目の要素の長さ $\left(l_{m}=2\{a \sin (\theta / 2)+(m-1) \Delta X \tan (\theta / 2)\}\right.$ $a:$ 円の半径, $\theta$ : 中心角)

また， $U_{m-1, n}^{(B)}$ と $U_{m, n}^{(B)}$ との間には式(2)の関係がある。

$$
U_{m-1, n}^{(B)}=U_{m, n}^{(B)}=\frac{\lambda_{m-1} l_{m-1} U_{m-1, n}+\lambda_{m} l_{m} U_{m, n}}{\lambda_{m-1} l_{m-1}+\lambda_{m} l_{m}}
$$

時間 $\Delta \tau$ 間に要素 $m$ 内に貯えられる熱量は要素 $m$ の 温度上昇に費やされるから， $\Delta \tau$ 間に要素 $m$ から要素 $m+1$ に移動する熱量 $Q_{m, m+1}$ とすると, 式(3)の関係が ある。

$$
Q_{m-1, m}-Q_{m, m+1}=c_{m} \rho_{m} \Delta X l_{m}\left(U_{m, n+1}-U_{m, n}\right)
$$

ただし, $c_{m}:$ 要素 $m$ の比熱

$\rho_{m}:$ 要素 $m$ の密度

$U_{m, n+1}: m$ 番目の要素の時間 $n$ から $\Delta \tau$ 後に おける温度

式(1)〜式(3)より，式(4)を得る ${ }^{122}$.

$\left\{\frac{\Delta X^{2}}{\kappa_{m} \Delta \tau} l_{m}-\frac{\lambda_{m-1}}{\lambda_{m-1}+\lambda_{m}}\left(l_{m-1}+l_{m}\right)-\frac{\lambda_{m+1}}{\lambda_{m}+\lambda_{m+1}}\left(l_{m}+l_{m+1}\right)\right\} U_{m, n}$

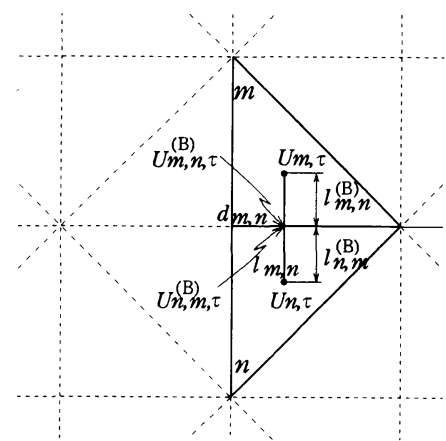

図-12 要素分割法の原理説明図 (2次元, 三角形要素分割)

$$
\begin{gathered}
+\frac{\lambda_{m+1}}{\lambda_{m}+\lambda_{m+1}}\left(l_{m}+l_{m+1}\right) U_{m+1, n}+\frac{\lambda_{m-1}}{\lambda_{m-1}+\lambda_{m}}\left(l_{m-1}+l_{m}\right) U_{m-1, n} \\
=\frac{\Delta X^{2}}{\kappa_{m} \Delta \tau} l_{m} U_{m, n+1}
\end{gathered}
$$

ただし， $\kappa_{m}: m$ 番目の要素の熱拡散率 $(\kappa=\lambda / c \rho)$ この場合，計算精度を上げるため $\theta, \Delta X, \Delta \tau$ の值を検 討しておく必要がある。

さらに, 空洞の形状や境界条件が複雑な場合には, 要素を三角形に分割し，温度分布を計算できる。こ の場合，次のような仮定をおく。

(1)熱は互いに隣接する要素の辺を通じて出入りす るものとする.

(2)各要素内部の温度は各々均一で，熱の授受は隣 接する要素の重心間で行われるものとする.

図-12に示すように要素 $m$ と要素 $n$ が隣接する場合, 時間 $\Delta \tau$ 間に要素 $m$ に要素 $n$ から入る熱量 $Q_{m, n}$ は式(5)で 与えられる。

$$
\begin{aligned}
Q_{m, n}= & -\lambda_{n} \frac{U_{n, m \perp}^{(B)}-U_{n, t}}{l_{n, m}^{(B)}} d_{m, n} \frac{l_{n, m}^{(B)}}{l_{n, m}} \Delta \tau \\
& -\lambda_{m} \frac{U_{m,}-U_{m, n, t}^{(B)}}{l_{m, n}^{(B)}} d_{n, m} \frac{l_{m, n}^{(B)}}{l_{m, n}} \Delta \tau
\end{aligned}
$$

ただし， $U_{m, ~}$ : 時間 $t$ における $m$ 番目の要素の温度 $U_{m, n, t}^{(B)}$ : 時間 $t$ における要素 $m$ の要素 $n$ との 境界の温度

$l_{m, n}:$ 要素 $m$ と要素 $n$ との重心間距離

$l_{m, n}^{(B)}: l_{m, n}$ のうち要素 $m$ の重心から要素 $n$ と の境界までの距離 $d_{m, n}:$ 要素 $m$ と要素 $n$ の境界の長さ

また， $U_{m, n, t}^{(B)}$ と $U_{n, m, t}^{(B)}$ との間には式(6)の関係がある. 


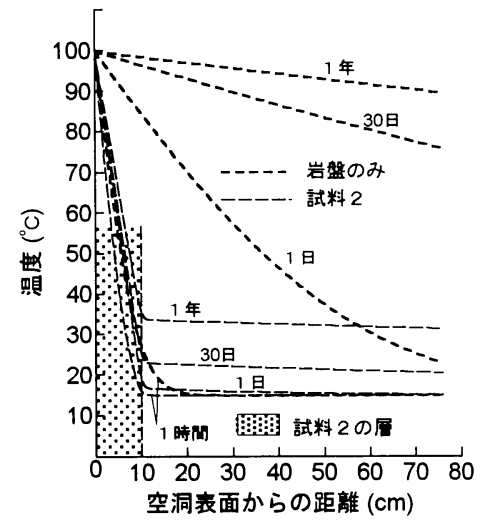

図-13 熱水貯蔵時の温度分布の経時変化

$$
U_{m, n, t}^{(B)}=U_{n, m, t}^{(B)}=\frac{\frac{\lambda_{m}}{l_{m, n}^{(B)}} U_{m, t}+\frac{\lambda_{n}}{l_{n, m}^{(B)}} U_{n, t}}{\frac{\lambda_{m}}{l_{m, n}^{(B)}}+\frac{\lambda_{n}}{l_{n, m}^{(B)}}}
$$

式(5)に式(6)を代入すると

$$
Q_{m, n}=\frac{\lambda_{m} \lambda_{n}}{\lambda_{m} l_{n, m}^{(B)}+\lambda_{n} l_{m, n}^{(B)}}\left(U_{m,}-U_{n, t}\right) d_{m, n} \Delta \tau
$$

隣接要素は3 個あるため, $\Delta \tau$ 時間内に要素 $m$ 内に 貯えられる熱量は要素 $m$ の温度上昇に費やされるか ら式(8)の関係がある.

$$
\sum_{n=1}^{3} Q_{m, n}=c_{m} \rho_{m} S_{m}\left(U_{m, t+\Delta t}-U_{m, t}\right)
$$

ただし, $S_{m}:$ 要素 $m$ の面積

$U_{m,+\Delta \tau}: m$ 番目の要素の時間 $t$ か $\Delta \tau$ 後 における温度

すなわち，時間 $t+\Delta \tau$ における要素 $m$ の温度は式 (9)で与えられる.

$$
U_{m, t+\Delta x}=\frac{\sum_{n=1}^{3} Q_{m, n}}{c_{m} \rho_{m} S_{m}}+U_{m, t}
$$

\section{(2) 解析方法}

水平および鉛直方向に十分な広がりをもつ，花岡 岩の地山を想定する.土被り $100 \mathrm{~m}$ の位置に，表面 に断熱材を施した仕上がりの内径 $10 \mathrm{~m}$ の円形空洞を 設け, 熱水 $\left(100^{\circ} \mathrm{C}\right.$ 一定)を貯蔵した場合の空洞周辺岩 盤に生じる非定常の温度分布の経時変化を要素分割 法 (三角形要素) にて求めた。花崗岩および断熱材 の熱物性値については前述の值を用いて解析した。

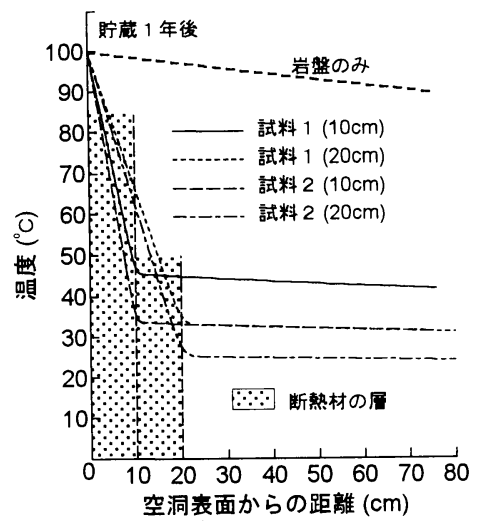

図-14 熱水貯蔵時の貯蔵 1 年後の温度分布

境界は地表，空洞表面から左右 $100 \mathrm{~m}$, 下方 $100 \mathrm{~m}$ の位置とし，境界の温度は $15^{\circ} \mathrm{C}$ 一定とした。また， 初期温度は岩盤部分, 断熱材部分は $15^{\circ} \mathrm{C}$, 空洞内部 は $100^{\circ} \mathrm{C}$ とた。

\section{(3) 計算結果および考察}

空洞の表面に $10 \mathrm{~cm}$ の厚さで試料2の断熱材を施し た場合の空洞周辺の温度分布を貯蔵1年後までとり まとめた結果が図-13である，比較のため断熱材を 施さない岩盤のみの場合も示している．断熱材を施 すことにより，空洞からの熱伝導に遅れを生じてい る. また，断熱材部分と岩盤部分における温度勾配 に大きく差がみられ，断熱材部分の勾配が急なのに 対し，岩盤部分ではほとんど勾配がない。これは断 熱材の熱伝導率が花岡岩に比べ, 極めて小さな值で あることに起因しているものと考えられる.

岩盤のみの場合, 試料1, 試料2をそれぞれについ て $10 \mathrm{~cm}$ および $20 \mathrm{~cm}$ の厚さで施した場合について, 貯蔵 1 年後における空洞周辺の温度分布をとりまと めたものが図-14である、いずれの断熱材を施した 場合も断熱材の厚みを増すと, 空洞周辺岩盤への熱 伝導により遅れが生じている．また，この場合試料 1よりも試料 2 の方が熱伝導により遅れが生じている. これらのことから，断熱材を施す場合には目的にあ った熱物性をもつ断熱材を選定し, 適切な厚みで施 エすることが必要であると考えられる.

\section{5. 空洞周辺の応力解析}

\section{(1) 解析方法}

ここでは 4 で得られた温度分布を用いて, 空洞周 
表-1 解析に用いた花崗岩の物性値

\begin{tabular}{|c|c|c|c|c|c|}
\hline $\begin{array}{l}\text { 温度 } \\
\left({ }^{\circ} \mathrm{C}\right)\end{array}$ & 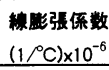 & 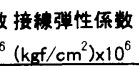 & ポアソン比 & $\begin{array}{l}\text { 圧縮強度 } \\
\left(\mathrm{kgf} / \mathrm{cm}^{2}\right) \\
\end{array}$ & $\begin{array}{r}\text { 引張强度 } \\
\left(\mathrm{kgf} / \mathrm{cm}^{2}\right)\end{array}$ \\
\hline $10 \sim 20$ & 0.0 & 0.51 & 0.16 & -1790 & 90 \\
\hline $20 \sim 30$ & 7.7 & 0.52 & 0.16 & -1770 & 88 \\
\hline $30 \sim 40$ & 7.7 & 0.53 & 0.16 & -1760 & 87 \\
\hline $40 \sim 50$ & 7.8 & 0.55 & 0.16 & -1740 & 85 \\
\hline $50 \sim 60$ & 7.9 & 0.56 & 0.16 & -1720 & 84 \\
\hline $60 \sim 70$ & 8.3 & 0.57 & 0.16 & -1710 & 82 \\
\hline $70 \sim 80$ & 8.6 & 0.58 & 0.16 & -1690 & 81 \\
\hline $80 \sim 90$ & 9.1 & 0.59 & 0.16 & -1670 & 79 \\
\hline $90 \sim 100$ & 9.6 & 0.60 & 0.16 & -1660 & 78 \\
\hline
\end{tabular}
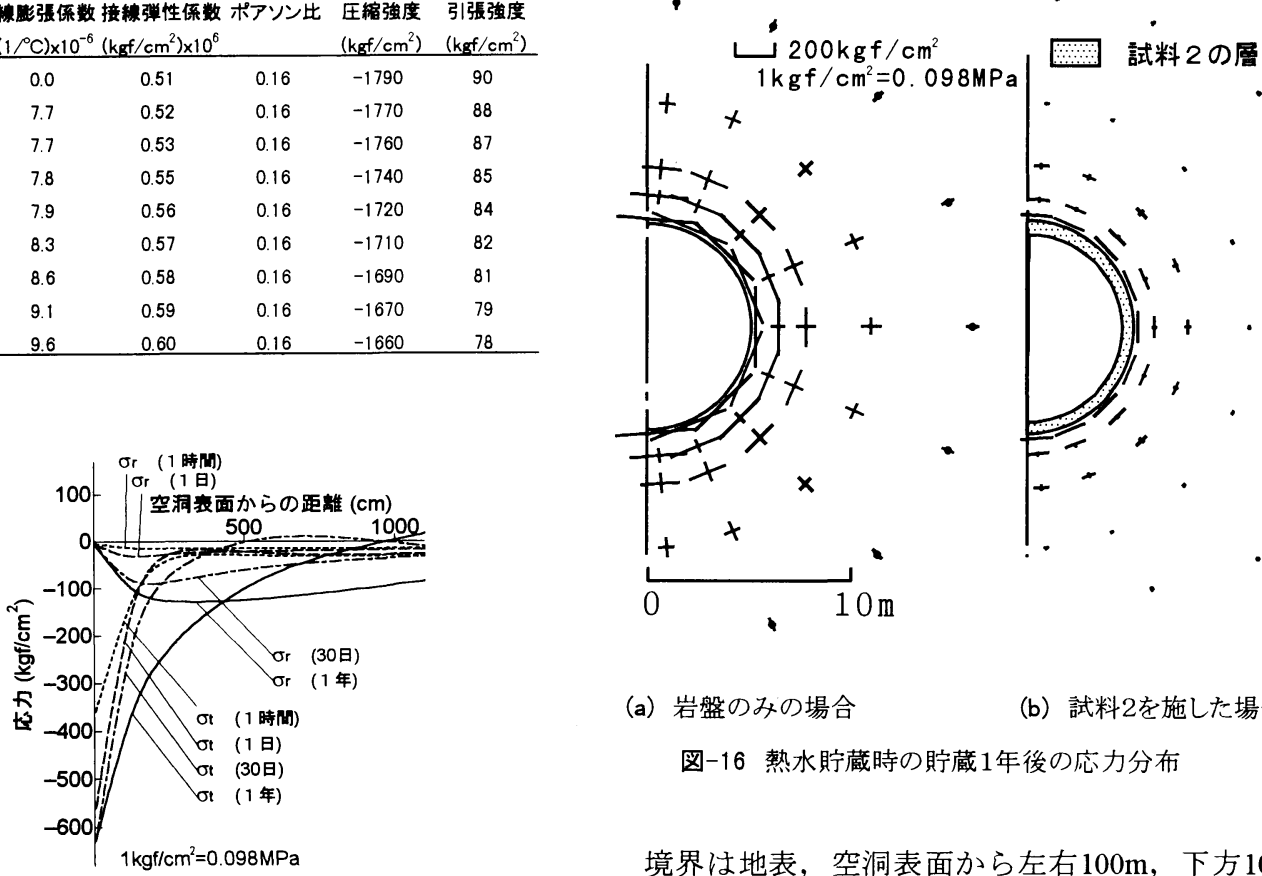
（a）岩盤のみの場合
（b）試料2を施した場合

図-16 熱水貯蔵時の貯蔵 1 年後の応力分布

境界は地表，空洞表面から左右 $100 \mathrm{~m} ， 下$ 方 $100 \mathrm{~m}$ （a）岩盤のみの場合

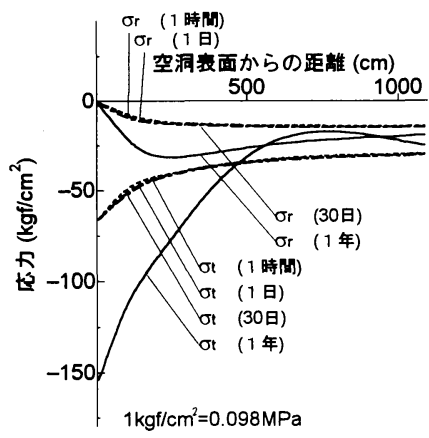

（b）試料2を施した場合

図-15 熱水貯蔵時の水平軸上の応力分布の経時変化

辺岩盤の応力分布を有限要素法に時間の概念を取り 入れ，2次元平面ひずみ問題として応力解析を行っ た．本解析では便宜上，亀裂のない新鮮な岩盤を想 定し, 破壊判定はMohrの応力円包絡線説 ${ }^{13}$ に従うも のとした。空洞掘削時の発破によるゆるみ領域はこ こではないものとした．解析に必要となる湿潤状態

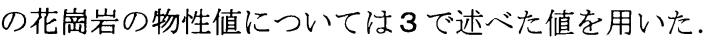
これを表-1に示す.
の位置とし，地表および左右の境界は自由端とし， 下方の境界は上下方向固定とした．空洞表面は自由 端とした。なお，空洞中心を通る鉛直線上では左右 方向固定とした。

初期応力としては岩盤の自重と自重の $1 / 2$ の側圧 がかかっているものとし，熱水を貯蔵することによ り，そこに式(10)で表される熱応力が重畳されるも のとした.

$$
\sigma_{t}=E_{T} \alpha_{T}\left(T-T_{0}\right)
$$

$$
\begin{aligned}
& \text { ただし, } \sigma_{t}: \text { 熱応力 } \\
& E_{T}: \text { 温度 } T \text { } \\
& \alpha_{T}: \text { 温度 } T \text { } \\
& T: \text { : 温度 } \\
& T_{0}: \text { 地山の弾性係数 } \\
& \text { 初期温度 }\left(15^{\circ} \mathrm{C}\right)
\end{aligned}
$$

\section{(2)解析結果および考察}

ここで断熱材として試料2の方が熱拡散率および 熱伝導率の值がいずれも試料 1 の $1 / 2$ 程度と小さく, 岩盤に遅く熱を伝えていることから試料2を用いた。

まず，熱水貯蔵時の空洞で中心からの水平軸上に 作用する接線方向および半径方向の応力の経時変化 を，岩盤のみの場合と試料2を $10 \mathrm{~cm}$ 施した場合とを 比較したものが図-15(a)，(b)である。また，貯蔵1 年後の応力状態をそれぞれ比較したものが図一 


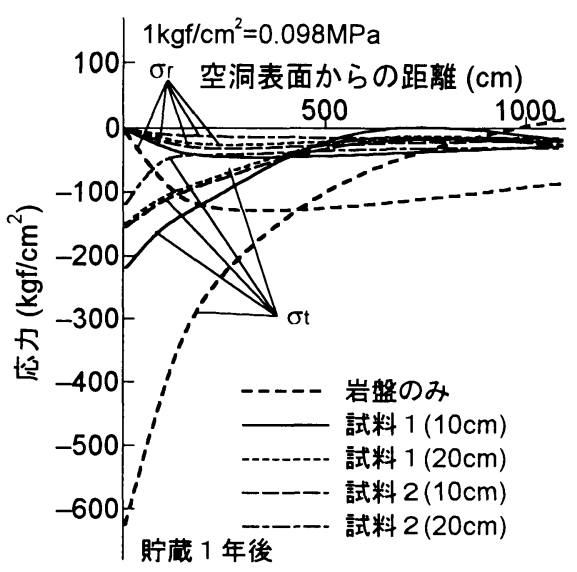

図-17 熱水貯蔵時の貯蔵 1 年後の 水平軸上の応力分布
16 (a)，(b)である。これらより，断熱材を施した場 合も岩盤のみの場合もいずれの場合にも，貯蔵開始 直後から空洞表面付近に大きな圧縮応力が空洞の接 線方向に発生していることがわかる．また，時間の 経過とともに圧縮応力は増大しており，地山内部人 も影響している.しかし，断熱材を施した場合には， 岩盤のみの場合に比べ, 空洞付近の接線方向の圧縮 応力は貯蔵 1 年後で $1 / 4$ 程度, 地山内部に発生する圧 縮応力も $1 / 2$ 程度であり，断熱材が熱応力の軽減に 有効な手段となり得ることがわかる．次に，岩盤の みの場合，試料 1 およ゙試料 2 をそれぞれ $10 \mathrm{~cm}$ おび $20 \mathrm{~cm}$ 施した場合について，貯蔵 1 年後における空洞 からの水平軸上に作用する接線方向および半径方向 の応力を示したものを図-17に示す.これより断熱 材の厚みを増加させた方が，より熱応力の軽減効果 は大きく，試料1より試料2を施した方が，より効果 が得られていることがわかる．また，試料 1 を $20 \mathrm{~cm}$ 施した場合と試料 2 を $10 \mathrm{~cm}$ 施した場合とを比較する と, 熱応力軽減の効果はほぼ同程度であった.

以上の結果, 断熱材を空洞表面に施すことにより 熱応力を軽減できるものと考えられるが，前述の様 に断熱材のひずみは岩石に比べて大きく, 施工の際 には繋ぎ目に適当な処置を施す必要があるものと考 えられる.また，熱水の影響を長時間受けることか ら，断熱材の耐久性についても検討する必要がある.

\begin{tabular}{|c|c|c|c|c|c|}
\hline $\begin{array}{l}\text { 温度 } \\
\left({ }^{\circ} \mathrm{C}\right)\end{array}$ & $\begin{array}{l}\text { 楾膨張係数 } \\
\left(1 /{ }^{\circ} \mathrm{C}\right) \times 10^{-4}(\end{array}$ & $\begin{array}{l}\text { 接線弾性係数 } \\
\left(\mathrm{kgf} / \mathrm{cm}^{2}\right) \times 10^{3}\end{array}$ & ポアソン比 & $\begin{array}{l}\text { 王㨭強度 } \\
\left(\mathrm{kgf} / \mathrm{cm}^{2}\right)\end{array}$ & $\begin{array}{l}\text { 引張強度 } \\
\left(\mathrm{kgf} / \mathrm{cm}^{2}\right)\end{array}$ \\
\hline $10 \sim 20$ & 0.0 & 0.18 & 0.43 & -14 & 118 \\
\hline $20 \sim 30$ & 1.3 & 0.17 & 0.43 & -13 & 110 \\
\hline $30 \sim 40$ & 1.4 & 0.17 & 0.44 & -13 & 103 \\
\hline $40 \sim 50$ & 1.5 & 0.16 & 0.44 & -12 & 95 \\
\hline $50 \sim 60$ & 1.6 & 0.15 & 0.44 & -11 & 87 \\
\hline $60 \sim 70$ & 1.7 & 0.15 & 0.44 & -11 & 80 \\
\hline $70 \sim 80$ & 1.8 & 0.14 & 0.44 & -11 & 74 \\
\hline $80 \sim 90$ & 1.8 & 0.13 & 0.44 & -10 & 68 \\
\hline $90 \sim 100$ & 1.8 & 0.13 & 0.44 & -10 & 63 \\
\hline
\end{tabular}

\section{6. 熱水の漏出防止に関する一考察}

\section{（1）解析方法}

ここでは熱水を空洞内に貯蔵する際の熱水の漏出 防止対策として, 高分子系材料を空洞表面にライニ ングした場合について解析を行った．解析モデルは 4 と同様にし，ここで，ライニングについては通常 のトンネルのように荷重をもたせるものではなく， 熱水の漏出防止対策としてのライニングであるので, 厚さは数 $\mathrm{mm} \sim 1 \mathrm{~cm}$ 程度で充分であると考えられる が，ここでは熱水の影響を受けることや，解析にて 高分子系材料の挙動を確認し得る厚さを考慮し, $3 \mathrm{~cm}$ のライニングの層を設け，仕上がり直径が $10 \mathrm{~m}$ な る場合を想定した。 また, 前述の熱応力軽減と漏出 防止対策を併用した場合として, 空洞表面に断熱材 の層を設け，さらに高分子系材料の層を断熱材の表 面に設けた場合について検討を行った.

解析モデルは前述の場合と同様に，空洞表面に厚 さ $10 \mathrm{~cm}$ の断熱材を施し，さらに高分子系材料を $3 \mathrm{~cm}$ の厚さでライニングして空洞の仕上がりの内径が $10 \mathrm{~m}$ となる場合を想定した．この場合，高分子系材 料，断熱材および岩盤はそれぞれ防水シート等で互 いに分離し，それぞれが自由に伸縮できる場合を想 定している．断熱材および高分子系材料の熱物性值 については2の值を用いて解析を行った。また，試

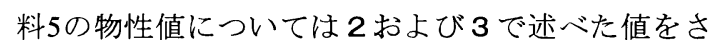
らに $10^{\circ} \mathrm{C}$ 毎に見積もった值を用いた。 その值につい ては表-2に示した。解析における境界条件, 初期条 件は 4 および 5 と同様にした。

\section{(2) 温度分布}

熱水貯蔵時の空洞周辺岩盤の温度分布の経時変化 を要素分割法にて求めた. ここでは高分子系材料と しては，熱拡散率が試料 1 およ゙試料 2 に比べて $1 / 2$ 


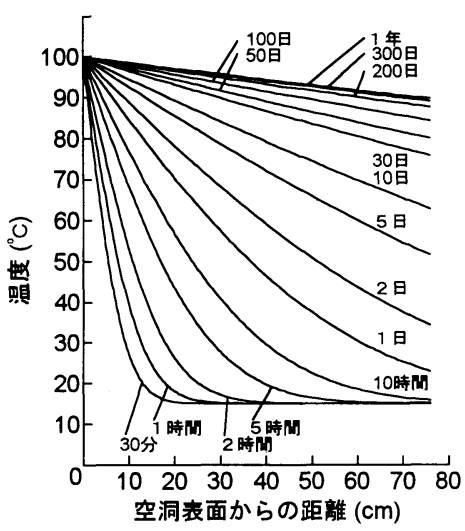

（a）岩盤のみの場合

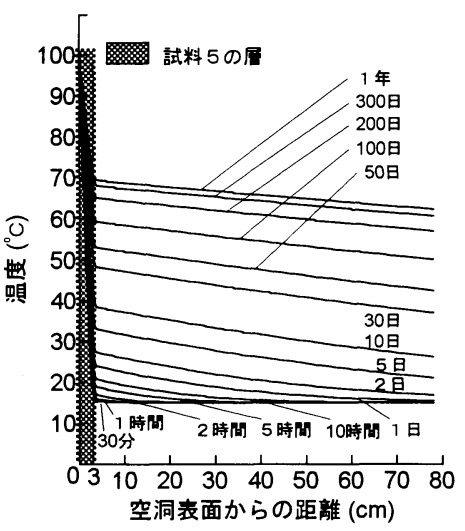

（b）試料5をライニングした場合

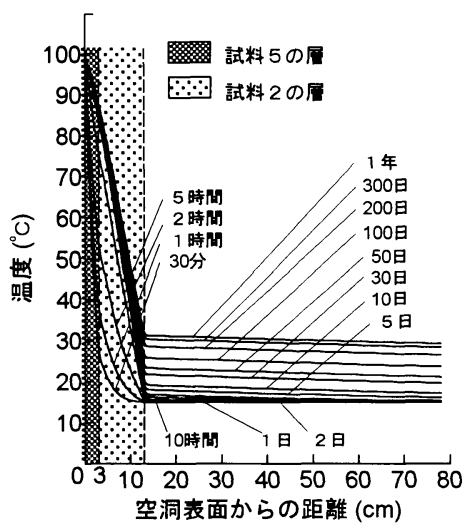

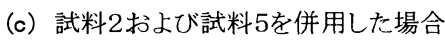

図-18 熱水貯蔵時の温度分布の経時変化

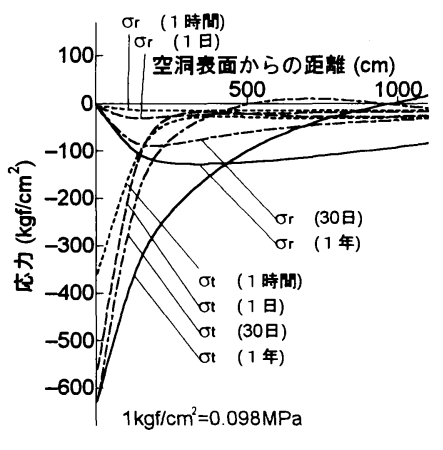

（a）岩盤のみの場合

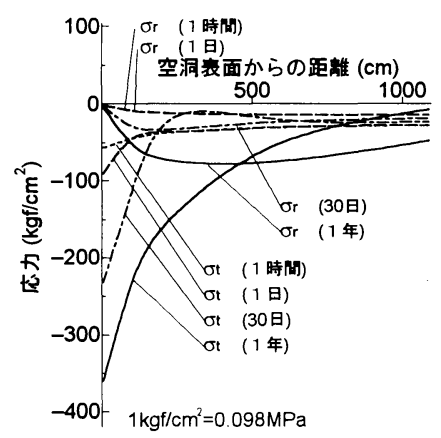

（b）試料5をライニングした場合

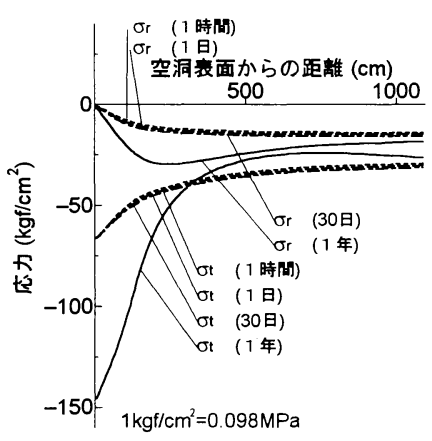

（c）試料 2 おび試料5を併用した場合

図-19 熱水貯蔵時の水平軸上の応力分布の経時変化

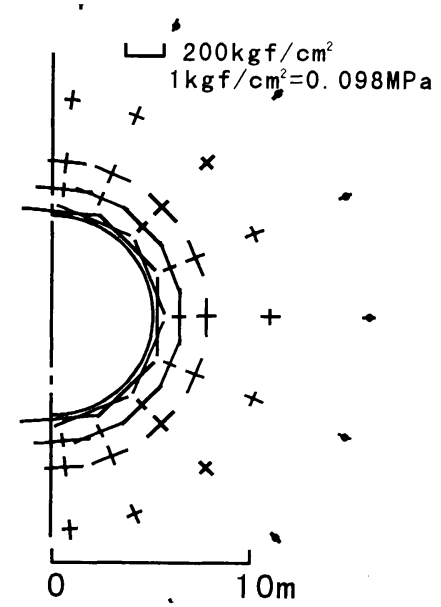

（a）岩盤のみの場合
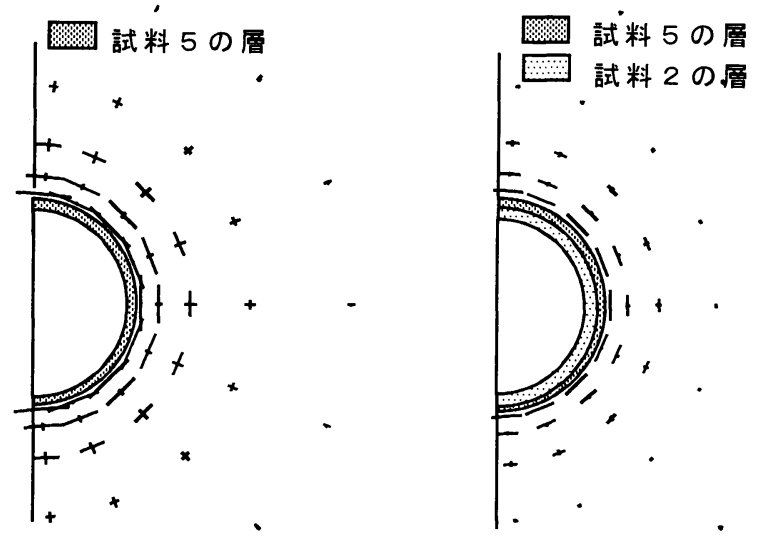

（b）試料5をライニングした場合

（c）試料 2 およ゙試料5を併用した場合

図-20 熱水貯蔵時の貯蔵 1 年後の応力分布 
と小さく, 熱伝導率も1/5 と小さことから試料 5 を 用いた。また，断熱材は前述と同様に熱拡散率およ び熱伝導率の值が試料 1 の $1 / 2$ 程度と小さい, 試料 2 を用いた。モデルとして，試料5のライニングを空 洞表面に $3 \mathrm{~cm}$ 設けた場合，試料2を空洞表面に厚さ $10 \mathrm{~cm}$ で施し, さらに, 試料 5 を厚さ $3 \mathrm{~cm}$ で断熱材の 表面にライニングした場合の結果を図-18 (a) - (c)に 示す.なお，比較のため岩盤のみの温度分布も示し ている、いずれも初期の時間には急激な勾配を示し ており, 空洞周辺にはまだ温度が及んでいないこと がわかる．しかし，時間の経過とともにその勾配は 緩やかになり，空洞周辺に温度が及んでいることが うかがえる．また，空洞表面から同一距離における 温度変化は, 時間の経過とともに緩慢となり, 貯蔵 1 年後には温度変化が極めて緩慢となる, いわゆる 準定常状態となることがわかる．また，試料5のラ イニングを設けた場合には，岩盤のみの場合に比心゙ 熱伝導に遅れがみられる。これは試料5の熱拡散率 および熱伝導率が花崗岩に比べ $1 / 20 \sim 1 / 80$ 程度と小 さいことから岩盤部分に遅く熱を伝えていることが わかる．また，断熱材および高分子系材料を併用し た場合には，高分子系材料部分，断熱材部分，岩盤 部分においてそれぞれ温度勾配が異なっており，断 熱材部分では急激な温度勾配を生じていることがわ かる.

\section{(3) 応力解析}

ここでは前述の温度分布をもとに応力分布の経時 変化を求めた. 熱水貯蔵時の空洞で中心からの水平 軸上に作用する接線方向および半径方向の応力の経 時変化を, 岩盤のみの場合, 試料5をライニングし た場合および断熱材および高分子系材料を併用した 場合とで比較したものを図-19 (a)-(c)に示す. また, 貯蔵1年後の応力状態をそれぞれ比較したものを図一 20 (a) - (c)に示す. これらより, 試料5をライニング した場合も，岩盤のみの場合も，いずれの場合にも 貯蔵開始直後から空洞表面付近に, 圧縮応力が空洞 の接線方向に発生し, 時間の経過とともに圧縮応力 は増大しているが，試料5をライニングした場合に は, 熱伝導に遅れがあるため, 岩盤のみの場合と比 較して, 熱応力の発生にも遅れがみられる。 また, 断熱材と高分子系材料を併用した場合は，断熱材の 効果により，断熱材の場合と同様に空洞表面付近の 接線方向の圧縮応力は $1 / 4$ 程度, 地山内部に発生す る圧縮応力も $1 / 2$ 程度で, 熱応力が軽減されている ことがわかる．また，いずれの場合においても高分 子系材料は熱膨張するが，破壊に至るような応力は 発生せず安定していることがわかった．以上の結果
から試料5をライニングすることは，熱水の漏出防 止対策として有効な手段となり得るものと考えられ る.

\section{7. 結言}

本研究では, 地山岩盤内空洞に熱水を貯蔵した場 合の漏出防止および熱応力軽減対策として, 空洞表 面に高分子系材料および断熱材を設けることを提案 し, 解析により空洞の安定性について検討を行った. 本研究で得られた結果を要約すると以下の通りであ る.

(1) 高温下における高分子系材料および断熱材のひ ずみは花岡岩よりも大きい.また，高分子系材料の 熱拡散率は花岡岩の $1 / 10$ 以下, 熱伝導率も断熱材て 花崗岩の $1 / 100$ 程度, 高分子系材料で $1 / 20$ 程度と小さ い.

(2) 高温下における高分子系材料の圧縮強度および 引張強度は温度上昇とともに低下する，接線弾性係 数も温度上昇とともに低下し, 接線弾性係数の值は 花崗岩に比べて非常に小さい.

(3) 熱応力軽減対策として, 断熱材を施すことにり, 熱応力を $1 / 2 \sim 3 / 4$ 程度軽減できることがわかった.

(4) 高分子系材料をライニングすることにより, 熱 水の漏出防止対策となり得るものと考えられる. ま た，熱応力軽減と熱水の漏出防止対策を同時に行う 方法として，断熱材と高分子系材料の層を空洞表面 に設けた場合，有効な方法となり得ることがわかっ た.

実際に，地山岩盤内空洞に熱水を貯蔵した場合， 貯蔵量の変動に伴い, 空洞周辺岩盤は熱の影響を繰 り返し受けることとなる. 熱履歴を受ける場合の空 洞周辺岩盤の挙動については別の機会に報告したい.

\section{参考文献}

1) Inada, Y., Kinoshita, N., Nakazaki, H. and Ueda, T. : Heated water storage in underground openings, Proc. 6th Int. Cong. IAEG., pp.2745-2750, 1990.

2) 稲田善紀, 木下尚樹, 中崎英彦, 上田貴夫 : 熱水貯蔵 時の空洞の安定性と漏水に関寸る基礎的研究, 土木学 会論文集, No.424/III-14, pp.227-234, 1990.

3) 稲田善紀, 木下尚樹, 関正造, 菊地慎二 : 断熱材を用 いた場合の空洞周辺岩盤の熱応力軽減に関する一考察, 第26回岩盤力学に関するシンポジウム講演論文集, pp.71-75, 1995.

4) Inada, Y., Kinoshita, N., Ueda, T. and Ochi, K. : Effect of 
adiabatical material on thermal stress reduction around openings due to heated water storage, Proc. of The KoreaJapan Joint Symp.on Rock Eng., pp.101-107, 1996.

5) 稲田善紀, 木下尚樹, 松嶋信行, 成行惊 : 高温の温度 履歴を受ける岩盤内空洞に関する一二の考察, 土木学 会地下空間シンポジウム論文・報告集, 第3巻（審査付 論文)，pp.139-148， 1998.

6) 稲田善紀, 木下尚樹, 上田貴夫, 甲村雄一, 松本喬 : 高温および低温の影響を受ける空洞周辺岩盤の熱的挙 動, 第10回岩の力学国内シンポジウム講演論文集, pp.593-598, 1998.

7) 稲田善紀 : 岩盤工学, pp.180-185, 森北出版, 1997.

8) 稲田善紀, 寺田 孚, 伊藤一郎 : 岩石の線膨張係数に
ついて, 水曜会誌, Vol.17, No. 5, pp.200-203, 1971

9) 稲田善紀 : 地下の空間利用, pp.101-103, 森北出版, 1989.

10)成沢郁夫: 高分子材料強度学, pp.67-73, オーム社, 1982.

11)稲田善紀, 横田公忠, 時川忠 : 熱水が岩石の強度およ び変形特性に及ぼす影響, 土木学会論文集, No.370/III 5, pp.217-223, 1986.

12)稲田善紀, 関正造 : 低温物質貯蔵時の液漏れおよび冷 気漏れ対策としての高分子系材料の適用性，土木学会 論文集, No.554/III-37, pp.259-268, 1996.

13)山口梅太郎, 西松裕一 : 岩石力学入門, pp.99-102, 東 京大学出版会, 1991.

(1997. 10.29 受付)

\title{
COUNTERMEASURES FOR SOME PROBLEMS RELATED TO STORAGE OF HEATED WATER IN OPENING EXCAVATED IN MOUNTAIN
}

\author{
Yoshinori INADA, Naoki KINOSHITA and Nobuyuki MATSUSHIMA
}

\begin{abstract}
The authors have proposed temporary storage of heated water in openings excavated in rock mountain. In this case, countermeasures for the reduction of thermal stress around openings and preventing leakage of heated water from openings become important. In this study, the authors proposed the reduction of thermal stress by using adiabatical material, resin lining system and combination lining system of resin and adiabatical material as a countermeasure for preventing leakage and reduction of thermal stress. The results of the test of physical properties of adiabatical material and resin at high temperature are described. And using these values, temperature distribution and stability of openings were analyzed and discussed.
\end{abstract}

